\title{
Carbon Tax Pricing And The Social Cost Of Carbon: The Case In The South African Motor Vehicle Manufacturing Industry
}

Suren Pillay, South African Revenue Service, South Africa Pieter W. Buys, North-West University, South Africa

\begin{abstract}
Since the implementation of carbon tax on motor vehicles in South Africa during 2010, the pricing of the tax has never been challenged or assessed. The purpose of this study is to gauge the reasonability of the carbon tax price in South Africa as applicable to the motor vehicle manufacturing industry. A detailed review is performed to determine the adequacy of the carbon tax price by comparing the social cost of carbon from motor vehicle emissions against the revenue raised from carbon tax levied on motor vehicles in the same period. Empirical research includes an exploratory questionnaire into the adequacy of the carbon tax price in South Africa with input data from multinational motor vehicle manufacturers operating in South Africa. The findings from the literature review confirm that although the respondents do not consider the level of carbon tax price as adequate to be relevant for the social cost of carbon, the revenue raised from this tax exceeds the social cost of carbon leading to the conclusion that the tax is adequately priced.
\end{abstract}

Keywords: Carbon Dioxide; Carbon Tax; Cap and Trade Scheme; Climate Change; Social Cost of Carbon

\section{INTRODUCTION}

\section{Background}

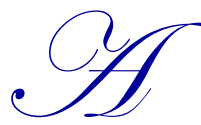

ccording to the Fourth Assessment Report of the Intergovernmental Panel on Climate Change (IPCC), the average global temperature had increased by $0.741^{\circ} \mathrm{C}$ during the period 1906 to 2005 , resulting in rising sea levels due to melting snow and ice ( $\mathrm{Li}$ et al., 2012). It is expected that greenhouse gas emissions will continue to increase over the next 30 years, resulting in even further rising sea levels and additional negative impacts on coastal ecosystems, among other (Hardisty, 2009). Governments therefore have to consider strategies and alternatives to reduce greenhouse gas emissions, such as $\mathrm{CO}_{2}$, if they wish avoid or even just to mitigate the negative impacts of climate change. Two 'mainstream' instruments available to governments to lower greenhouses gas emissions include i) cap and trade schemes, which limits the quantity of allowable emissions with a final carbon price being established through trade allowances, and ii) carbon taxes, which seeks to reduce emissions through the pricing of emissions (National Treasury, 2010).

Cap and trade schemes originated from the Kyoto Protocol, which is a legally binding agreement signed by a host of industrial countries in December 1997 to reduce greenhouse gas emissions (Wittneben \& Kyar, 2009; Kyoto, 2010; UNFCC, 2010). These schemes are regulatory measures designed to achieve environmental objectives at the lowest social cost by making pollution credits available to those who are best equipped to make the desired changes (Harwatt, 2008). Carbon tax, on the other hand, is a market-based instrument that creates a cost to emissions by directly taxing the carbon content of fuels (Hasset $e$ al., 2007). The purpose of a carbon tax is to internalise externalities related to anthropogenic climate change (Metcalf, 2009). A recent study concluded that South Africa is a major exporter of carbon; at least 129 per cent more carbon is associated with a dollar earned with exports than a dollar spent on imports with such figures having serious policy-related implications in a future where international climate-change trade limitations will become stricter and binding (Brent et al., 2009). 
Within the South African context, the National Treasury (2010) published a discussion document considering the economic merits for introducing a carbon tax in South Africa in December 2010, which highlighted their reasons for leaning towards carbon taxes as a method of limiting the social cost of carbon (or SCC). The discussion document evaluated the case for carbon tax against cap and trade schemes and concluded that carbon tax was the best policy instrument for South Africa as it was administratively easy to manage and minimised opportunities for abuse due its simple structure. Estimates of the social cost of carbon were also briefly reviewed in the discussion paper as a guideline in determining the South African carbon tax price, which was suggested to be R75 per ton of $\mathrm{CO}_{2}$ with an increase to approximately R200 per ton $\mathrm{CO}_{2}$ (National Treasury, 2010). The actual carbon tax price implemented on 1 September 2010 on the sale of new passenger motor vehicles in South Africa was R75 for every gram of carbon dioxide per kilometre it emits over the 120g/km (NAAMSA, 2011; Shirley, 2010). It should be noted that, since the introduction of carbon tax in South Africa, the ability of a carbon tax policy to actually reduce $\mathrm{CO}_{2}$ emissions has been questioned, but not assessed (Nel \& Nienaber, 2012).

The SCC has been defined as the amount of damage caused by each additional ton of greenhouse gas emitted into the atmosphere (Hardisty, 2009; Pearce, 2003). Hardisty (2009: 209) further states that the damage cost specifically relates to the probable impacts to the global economy caused by increases in global temperatures, rising sea levels, weather-related events, declining agricultural production and loss of biodiversity, among others. In terms of economic theory, in conditions of a perfect market where all social costs have been considered, any efforts to cut back the emissions of greenhouse gases would be feasible as long as the incremental cost of reducing the emission is lower than the increase in SCC (IPCC, 2012). Applying this general economic principle to the carbon tax scenario, we therefore argue that the SCC should be equal to, or lower than, revenues generated from carbon taxes in order for the instrument of carbon tax to be feasible.

\section{Problem Statement, Objectives and Research Method}

Following from the above, the potential knowledge gap this paper explores is found in its attempt to determine the adequacy of carbon tax revenues generated in compensation for the damages caused by related carbon emissions. It is acknowledged that this in itself is not a simplistic task and that there are multiple variables at play in such an endeavour. Notwithstanding, the key objective of this paper is to examine the SCC from a South African motor vehicle industry perspective, to which two supporting research questions have been formulated as follows:

$\mathbf{P}_{1}$ : What is the (perceived) level of understanding by the South African motor vehicle manufacturers of the SCC, the implications of carbon taxes on their operations and the adequacy of such taxes?

$\mathbf{P}_{2}$ : Is the South African carbon tax price pertinent to the motor vehicle industry adequately priced to compensate for the monetary damage caused by emitting one additional ton of carbon dioxide into the atmosphere?

The study comprises an exploratory study and analysis with both literature and empirical components. With regard to the first question as set out above, an exploratory study into the motor vehicle manufacturers' perceptions and understanding of the SCC and of the adequacy of the carbon tax pricing, as well as the impact of carbon tax on their business operations was conducted by way of a questionnaire developed based on an underlying literature study, utilising an appropriate four-point Likert-type response scale. The overall targeted population was the eight multinational vehicle manufacturers producing/assembling motor vehicles in South Africa. It should be noted that Renault and Nissan entered into a global alliance agreement, which effectively results in them becoming 'one manufacturer' in the South African context (Anon, 2013). Since there is such a limited number of manufactures available, all the companies were initially approached, with three of them offering their willingness to participate in the study. The researcher was available during the survey to provide guidance and clarification, should the respondents have had questions regarding the survey.

With regard to the second question as set out above, a detailed review quantifying the SCC of motor vehicles manufactured in South Africa has been identified in order to determine the adequacy of carbon tax pricing in South Africa. The total level of carbon emissions attributable to motor vehicles manufactured in South Africa in 2011 was identified and the total damage due to $\mathrm{CO}_{2}$ emissions emitted from these vehicles was established using cost of carbon estimates from previous research projects. It should be noted that as carbon emissions tax on all passenger motor vehicles in South Africa was implemented on 1 September 2010 (NAAMSA, 2011), the first 
complete year in which carbon tax was fully operational was the 2011. Since carbon tax is levied only on newly manufactured vehicles, the related tax revenues generated in 2011 had to be matched to motor vehicles that were manufactured in the same period. This is the reason for using carbon emissions attributable to motor vehicles manufactured in 2011 exclusively.

The revenue received by the South African Revenue Service (SARS) in respect of carbon tax on motor vehicles was obtained and compared to the cost of $\mathrm{CO}_{2}$ emissions by motor vehicles manufactured in 2011 to determine whether the carbon tax price adequately covered the total damage costs associated with carbon emissions from motor vehicles manufactured in 2011.

\section{MOTOR VEHICLE MANUFACTURERS AND SCC}

In achieving the first objective, an exploratory questionnaire was distributed to the motor vehicle manufacturers in South Africa. Table 1 below presents a brief analysis of the descriptive statistics associated with the responses received from the respondents in respect of each question.

Table 1: Descriptive Statistics of Responses

\begin{tabular}{|l|c|c|c|c|}
\hline Question no & Min Statistic & Max Statistic & Mean Statistic & Std Dev Statistic \\
\hline 1 & 1 & 3 & 1.67 & 1.12 \\
\hline 2 & 4 & 4 & 4.00 & 0.00 \\
\hline 3 & 4 & 4 & 4.00 & 0.00 \\
\hline 4 & 4 & 4 & 4.00 & 0.00 \\
\hline 5 & 1 & 4 & 2.00 & 1.73 \\
\hline 6 & 1 & 4 & 2.00 & 1.73 \\
\hline 7 & 1 & 4 & 2.33 & 1.53 \\
\hline 8 & 3 & 4 & 3.67 & 0.58 \\
\hline 9 & 1 & 4 & 2.33 & 1.53 \\
\hline 10 & 1 & 4 & 2.33 & 1.53 \\
\hline
\end{tabular}

The questionnaire was divided into two main sections, as indicated by the responses below:

\section{Section I: Carbon Tax Compliance}

The first part of the questionnaire focused on whether the respondents think there is a need for carbon tax and their overall compliance with carbon tax legislation. Question 1 asked whether there is a need for carbon tax in South Africa, question 2 enquired as to whether the respondents were aware of all carbon tax legislation and regulations, question 3 attempted to confirm whether there existed adequate internal controls over the carbon tax, and question 4 asked whether the respondents comply with all carbon tax legislation and regulations.

- $\quad$ Question 1 (score: 1.67): The majority of the respondents do not consider there to be a need for a carbon excise tax on motor vehicles in South Africa.

- $\quad$ Question 2 (score: 4): All of the respondents confirmed that they aware of the carbon tax legislation and regulations applicable to the motor vehicle industry in South Africa.

- $\quad$ Question 3 (score: 4): All of the respondents were of the opinion that there exists adequate internal controls over the recognition, measurement, recording and payment of carbon tax applicable to motor vehicles.

- Question 4 (score: 4): All of the respondents in the study also confirmed that they comply with all carbon tax legislation and regulations applicable to motor vehicles.

It would therefore seem that although the motor vehicle manufactures do not particularly agree with the need of carbon tax in their institutions, they do comply with the applicable regulations.

\section{Section 2: Carbon Tax Pricing and Impact on Manufacturing}

The second part of the questionnaire focused on the pricing of carbon tax as well as the impact of the tax on production techniques and fuel efficiency of motor vehicles manufactured. Question 5 enquired about the impact of carbon tax on production techniques and technologies toward producing more fuel efficient vehicles, while question 
6 focused on whether carbon tax has resulted in an improvement in the fuel efficiency of motor vehicles manufactured. Question 7 attempted to determine the impact of carbon tax on corporate social investment (CSI), question 8 enquired as to the awareness of the concept of the SCC among the respondents, question 9 enquired as to the adequacy of the current carbon tax price, while question 10 focused on whether carbon tax is the best policy decision from a climate change perspective.

- $\quad$ Question 5 and Question 6 (score: 2): No specific conclusions could be reached regarding the impact of carbon tax on production techniques, technology and the production of more fuel efficient vehicles within the South African context. The average answer obtained for both questions was mid-way in between the two extremes.

- $\quad$ Question 7 (score: 2.33): No specific conclusion could be made on whether the implementation of carbon tax has affected the respondents' CSI policy and/or behaviours. The average answer obtained for this question lies approximately mid-way in between the two extremes.

- $\quad$ Question 8 (score: 3.67): With regard to the awareness, the majority of the respondents are aware of the concept of the social cost of carbon.

- $\quad$ Question 9 and Question 10 (score: 2.33): There was no clear indication of whether the respondents consider the carbon tax price to adequately compensate for the damage caused by carbon emissions from motor vehicles or whether carbon tax is the best policy measure in addressing South Africa's climate change concerns.

A possible explanation for the inconclusive answer in question 5 is that the respondents' production techniques and technologies might vary with respect to the level of automated capacity versus labour intensity. A possible reason for the inconclusive answer to question 6 is that carbon emission reduction strategies differ among respondents with some respondents taking a more aggressive short-term approach as opposed to a more long-term gradual approach to carbon emission reductions. The variability in respondents' answers in respect of question 7 could lie in the impact of other factors such as company economic performance and market conditions on the internal CSI policies. On a factual basis, however, $66.67 \%$ of respondents do not agree (subject to exceptions) that the implementation of carbon tax has affected their CSI policy and/or behaviour. The average answer obtained for both questions was mid-way in between the two extremes. On a factual basis, $66.67 \%$ of respondents do not agree subject to exceptions that the carbon tax price adequately compensates for the damage caused by carbon emissions from motor vehicles, with a similar $66.67 \%$ that do not agree that carbon tax is the best policy measure in addressing South Africa's climate change concerns.

\section{THE ADEQUACY OF CARBON TAX PRICING}

In addressing the second objective pertaining to the adequacy of carbon tax revenues generated, the concept of quantifying damage costs associated with carbon emissions using quantification models together with the results of prior published research studies in determining an appropriate South African carbon tax cost was explored, which was followed by an evaluation of the adequacy of the carbon tax price by comparing the total estimated cost of damage caused by carbon emissions associated with manufactured vehicles to the revenue raised from levying the relevant carbon tax in the same period.

\section{Quantification of the Monetary Damage of Carbon}

Attributing a monetary cost to the damage caused by carbon emissions is important as it allows for a proper benefit analysis of the feasibility of a particular abatement instrument. Opponents of the quantification of damage caused by carbon emissions, however, argue that the true SCC cannot be determined as the effect on future generations is not yet fully known (Pearce, 2003). In determining the potential impact of carbon emissions, USG (2012) states that both scientists and economists face difficult challenges as there are always uncertainties and a lack of information about the future emissions of greenhouse gases as well as the effect of past and future emissions on the current climate system. Notwithstanding, several studies have attempted to quantify the SCC, or have attempted to evaluate the adequacy of carbon tax-related revenues to compensate for such SCC. 
Within the South African context, the following provides an indicative estimate of the potential damage costs associated with carbon-related climate change (Midgley et al., 2007):

- $\quad$ Flood damage costs in the Western Cape Province due to extreme rainfall events in the period from 2003 to 2007 have been estimated at around R1 billion.

- $\quad$ Coastal storm damage along the Durban coast in KwaZulu-Natal due to extreme weather events in 2007 have been estimated at around R100 million.

- $\quad$ Forestry losses during the 1991/1992 drought have been estimated at around R450 million.

- Drought impacts on agriculture 1983/84 have been estimated at be around R2.2 billion, and in 1991/92 to be around R3.5 billion.

In challenging the adequacy of carbon tax pricing, it is important to consider the distributional effects of a carbon tax. For illustrative purposes, various studies have been conducted in attempting to quantify the monetary impact of carbon tax on human society and welfare such as the following:

- In a study attempting to determine the effect of carbon tax on welfare in Italy, it was noted that the introduction of the tax had the effect of increasing welfare losses in households, with welfare losses increasing from $€ 225,000,000$ in 1995 to $€ 938,820,000$ in 2000 (Tiezzi, 2005).

- The quantitative welfare impact of carbon tax was also evaluated in a case study conducted in the United States on a 30 bus network, where it was noted that a uniform carbon tax would result in economic welfare losses of $\$ 2,700,000$ (He et al., 2012).

- In China, the impacts of various carbon tax schemes on household disposable income, household welfare, and economic growth were compared using a general equilibrium model indicating that a carbon tax will not only widen the urban-rural gap, but also result in welfare damage by reducing household savings by approximately $¥ 20,000,000,000$ (Liang \& Wei, 2012).

The studies above confirm instances where carbon tax was not the optimal policy choice in terms of welfare and distributional effects as the net impact of the implementation of carbon tax resulted in welfare losses. In such situations, one may conclude that the benefits of implementing a carbon tax will not exceed the SCC. Theoretically therefore, if the price of the carbon tax does not match the SCC in South Africa, one may expect similar welfare losses to those noted above.

\section{Quantification Models for Determining the SCC}

The SCC is often determined by economists using Integrated Assessment Models (IAMs), because they attempt to include knowledge from various fields of study (such as engineering, technology, behaviour and climate science) for the purpose of determining whether climate change policies are economically efficient (WRI, 2012). In South Africa, recent studies have incorporated the use of computer generated equilibrium (CGEs) models to determine the economy-wide impacts of a carbon tax, and while these are precise and functional, the static nature of CGE models often make them unsuitable for modelling the impacts of long-term problems such as climate change with significant uncertainty (National Treasury, 2010). In consideration of carbon prices, Table 2 below summarises the estimated carbon prices across different years by different research projects.

Table 2: Summary of Carbon Prices Estimates

\begin{tabular}{|l|c|c|}
\hline No & Study & CO $_{2}$ price per ton (SA Rand) \\
\hline 1 & Devarajan (2009) & 96.25 \\
\hline 2 & Winkler/Marquaard (2009) & 200.00 \\
\hline 3 & Long-term mitigation (2008) & 100.00 \\
\hline 4 & Metcalf (2008) & $123.45^{*}$ \\
\hline 5 & Nordhaus (2008) & $699.55^{*}$ \\
\hline 6 & Stern Review (2007) & $210.90^{*}$ \\
\hline 7 & Fankhauser (1994) & $140.18^{*}$ \\
\hline 8 & Nordhaus (1991) & $22.08^{*}$ \\
\hline
\end{tabular}

(* Foreign currencies are converted to South African Rand at the relevant exchange rate.) Sources: National Treasury (2010); OANDA (2012); Devarajan et al. (2009) 
An analysis of the estimates above reveals a range of so-called carbon prices over different periods. In terms of the sample of studies reflected in the above table, it should be noted that only three studies, i.e. the Longterm mitigation, Winkler/Marquaard and Devarajan studies, were specific to the South Africa context, with the Long-term mitigation and the Devarajan studies using CGE models to determine the estimate of the carbon price. It is submitted that the three South African studies should be used as a basis of determining the appropriate estimated South African carbon tax price as they are more specific to the South African context. The mean average of the three studies therefore confirms an average carbon tax price of R132.08 per ton of carbon.

\section{The Adequacy of Carbon Tax Pricing in South Africa}

The adequacy of carbon tax pricing has been assessed by comparing the benefits of introducing a carbon tax (as evidenced by tax revenue generated) per tax statistics published by the Department of National Treasury and comparing this revenue against the cost of carbon (as calculated above) in respect of emissions by newly manufactured motor vehicles in 2011 (being the latest complete data available at the stage of the research). The actual cost of carbon was then computed by multiplying South African carbon tax emissions from motor vehicle emissions against the carbon tax price. South African carbon emissions from motor vehicles have been estimated using reports from the United Nations, Statistics South Africa and the World Bank. The following steps were employed to test the adequacy of the carbon tax price on motor vehicles in South Africa:

Step 1: The total level of carbon emissions in South Africa

The historical carbon emission levels in South Africa are available up to 2010 using data published by the United Nations (UN, 2012). Growth rates have been determined over the most recent prior five-year period, and the average growth rate of $3.2 \%$ has then been used to estimate the carbon emissions for South Africa in 2011 (refer graph 1 below).

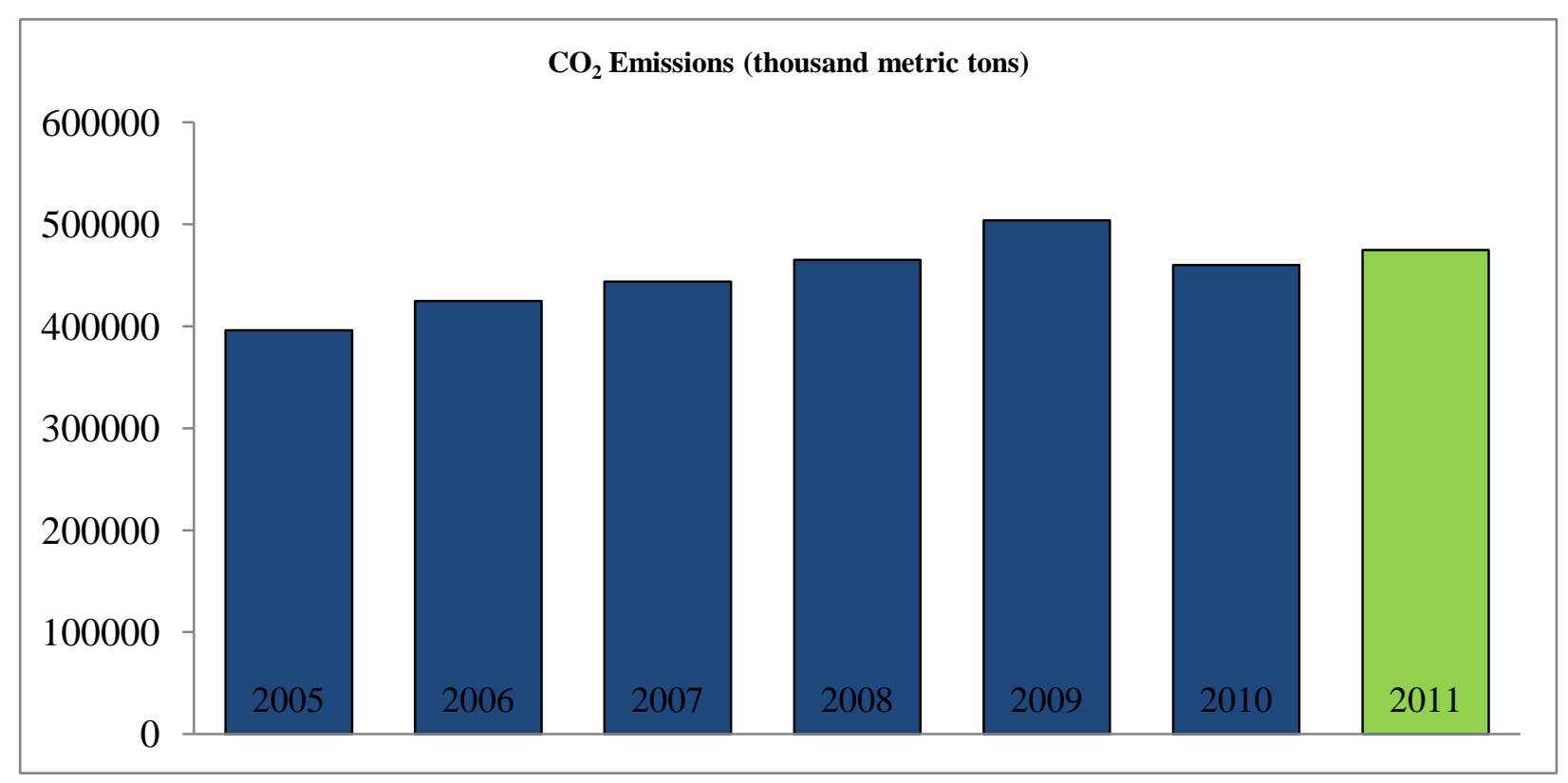

Graph 1: Carbon Emissions in South Africa

Source: (adapted and forecasted from UN, 2012)

As illustrated above, extrapolating the historical carbon emission trends in South Africa brings the total estimated $\mathrm{CO}_{2}$ emissions for 2011 at 475,004,400 metric tons (across all industries).

Step 2: The total level of carbon emissions attributable to the motor vehicle industry 
Since carbon tax is levied only on newly manufactured vehicles, the related tax revenues generated had to be matched to these vehicles. 2011's total carbon emission estimate therefore had to be adjusted to reflect the motor vehicles manufactured in 2011. The total carbon emissions (expressed in tons) from motor vehicles manufactured were derived indirectly as there was no direct literature source for this statistic. Firstly, the total carbon emissions in 2011 attributable to the motor vehicle industry were obtained from the Devarajan study (as above), which estimated the total carbon emissions attributable to the motor vehicle industry at around $10 \%$ of the country's total $\mathrm{CO}_{2}$ emissions (Devarajan et al., 2009). Under the assumption that the percentage is stable on a year-to-year basis, the estimated figure comes to $47,500,440$ tons of carbon emitted by the motor vehicle industry in 2011 . This estimate, however, includes emissions from 2011 and prior years' vehicles.

According to the World Bank (2012) and Statistics South Africa (2005-2011), there were 5,926,372 vehicles in South Africa in 2011; while, according NAAMSA (2012), there were 532,545 vehicles manufactured and sold in the same year. The ratio manufactured motor vehicles to the total motor vehicles is therefore $8.9 \%$ (or 532,545 vehicles $/ 5,926,372$ vehicles). Following hereon, the estimate of total carbon emissions in respect of the 2011 motor vehicles amounts to $4,227,539$ tons (or $8.9 \%$ of $47,500,440$ tons).

Step 3: Evaluate the adequacy of carbon tax revenues

In order to evaluate the adequacy of revenues generated, the total carbon emissions attributable to motor vehicles manufactured in 2011 (4,227,539 tons as calculated in step 2 above) are firstly multiplied by the carbon tax cost (R132.08 per ton as determined earlier) to arrive at a calculated SCC of motor vehicles manufactured in 2011. This results in an estimated social cost of carbon from 2011 motor vehicles manufactured of R558,373,372 (R132.08*4,227,539 tons of carbon). Secondly, according to National Treasury and South African Revenue Service (2012), the related carbon tax revenue received by the SARS amounted to R626,000,000 in 2011 and $\mathrm{R} 1,617,000,000$ in 2012, respectively. As carbon tax was implemented on 1 September 2010, it is submitted that a reasonable figure of revenue for 2011 would be R208,667,000 (being an average estimate for January and February 2011) plus R1,347,500,000 (being an average estimate for March to December 2011), which brings the total calculated revenue for 2011 to R1,556,167,000. On a high and estimated level, the carbon tax revenues therefore exceed the estimate of the social cost of carbon in respect of motor vehicles manufactured in 2011 quite substantially. It would therefore seem that the carbon excise tax price in South Africa more than adequately covers the SCC and passes the cost-benefit reasonability test in terms of policy-making.

\section{DISCUSSION AND CONCLUSION}

In addressing the key objective as set out earlier, this article explored the social cost of carbon and carbon taxes within the context of the South Africa motor vehicle manufacturing industry, and then specifically the industry's awareness thereof together with the adequacy of the tax revenue generated per the objective of the tax policies.

In respect of the first objective as specified, in terms of overall carbon tax compliance, though the majority of respondents considered that there is no need for a carbon tax in South Africa. It was further noted in terms of carbon tax policies that the majority of the respondents do not agree that carbon tax is the best policy measure in addressing South Africa's climate change concerns. Notwithstanding, all the respondents confirmed that they were aware of carbon excise tax legislation and regulations. The respondents also confirmed that they maintained adequate internal controls over carbon taxes collected. It was further noted that all the respondents are in compliance with all carbon tax legislation and regulations. Furthermore, in terms of the carbon tax impact on manufacturing, no conclusions could be drawn on the impact of the tax on production techniques and the fuel efficiency of motor vehicles manufactured. This could be due to the variation on production techniques and technology applied by different motor vehicle manufacturers in South Africa. With regard to their CSI policies, the majority of the respondents did not think that carbon tax would impact on its CSI expenditure. In terms of awareness of the concept of the social cost of carbon, the majority of the respondents confirmed that they are aware of the concept.

In respect of the second objective as specified, it would seem that the majority of respondents do not think (subject to exceptions) that the current carbon tax price adequately compensates for the damage caused by carbon 
emissions from motor vehicles. However, when considering the estimated level of carbon emissions of the relevant vehicles manufactured, and considering the revenues generated by the carbon on such vehicles, it would seem that the tax price is adequately levelled to compensate for the SCC related to the applicable vehicles. Notwithstanding the adequacy of the tax revenue generated, it remains a point of contention whether these revenues generated for the government coffers will in effect be used for related SCC issues, or whether it will just disappear into the general government revenues.

Looking at the results of the study as whole, one may conclude that South African motor vehicle manufacturers comply with carbon tax regulations and laws; however, the impact of carbon tax on production techniques and fuel efficiency on vehicles is still not truly established. Another important finding is that local motor vehicle manufacturers do not consider carbon tax to be the best climate change policy instrument for South Africa. This could be due to a number of reasons including the belief that the price of the tax has not adequately considered the price elasticity of demand relating to motor vehicles manufactured in South Africa or the perception that the SCC is actually greater than the carbon tax price.

\section{Limitations and Future Research}

With regard to the exploratory nature of this study, certain assumptions have been made and applied in determining the adequacy of the pricing of carbon tax constitute limitations. These assumptions included using an average growth rate in determining the carbon emissions for 2010 and 2011, as well as that the motor vehicle industries' proportionate share of carbon emissions in 2011 was similar to that of 2009. These assumptions may result in distortions in the final quantitative analysis of the reasonability of the carbon tax price.

Furthermore, even though the sample size may be considered small, the fact is that there are only limited motor vehicle manufacturers in South Africa, of which a substantial portion did participate in the study. Notwithstanding, the reader must take cognisance of this fact and be careful to generalise any findings to the motor vehicle industry per se, but such findings should be read and understood within the context of this study. A further limitation is that carbon tax might also be more or less relevant to a motor vehicle manufacturer depending on the existing level of fuel efficiency of vehicles manufactured. The depth and accuracy of answers provided in the questionnaire could therefore hinge on the existing level of fuel efficiency of motor vehicles manufactured.

A very topical future research opportunity lies in the fact that a national carbon tax is to be implemented by the National Treasury in South Africa as from 2015. Contributing studies into the pricing of such taxes will be of significant importance as the tax will be applicable to almost all companies operating in South Africa.

\section{AUTHOR INFORMATION}

Suren Pillay is a Chartered Accountant (SA) and works at the Large Business Centre section of the South African Revenue Service (SARS) Kwazulu-Natal. Suren is currently a Ph.D. candidate at the North-West University in South Africa's Potchefstroom campus. This article is based on the research conducted for his $\mathrm{PhD}$ degree in Taxation. School of Accounting Sciences, North West University, Private Bag X6001, Potchefstroom, 2520, South Africa.

Professor Pieter W. Buys is currently the Research Program Leader at the North-West University (South Africa) and holds two PhDs (Accountancy and Management Accountancy), two Masters Degrees (MComm and MBA), and he is also a US Certified Management Accountant (CMA). School of Accounting Sciences, North West University, Private Bag X6001, Potchefstroom, 2520, South Africa. E-mail: Pieter.Buys@nwu.ac.za. (Corresponding author)

\section{REFERENCES}

1. Anon. (2013). "Key facts of the Renault-Nissan alliance". Available: http://www.renault.com/en/Groupe/lalliance-renault-nissan/Pages/l-alliance-renault-nissan.aspx Date of Access: 5 Oct. 2013.

2. Brent, A., Hietkamp, A, Wise, R. \& O'Kennedy, K. (2009). "Estimating the carbon emissions balance for South Africa”. South African Journal of Economic and Management Sciences, 12(3): 263-279. 
3. Devarajan, S., Go, D.S., Robinson, S. \& Thierfelder, K. (2009). "Tax Policy to Reduce Carbon Emissions in South Africa." Report prepared for the World Bank program for Africa region climate change strategy. $36 \mathrm{p}$.

4. Hardisty, P.E. (2009). "Analysing the role of decision-making economics for industry in the climate change era." Management of Environmental Quality: An International Journal, 20(2): 205-218.

5. Harwatt, H. (2008). "Reducing carbon emissions from personal road transport through the application of a tradable carbon permit scheme: Empirical findings and policy implications from the UK."Institute for Transport Studies, University of Leeds, 29p. (Unpublished)

6. Hasset, K.A., Aparna, M. \& Metcalf, G.E. (2007). "The incidence of U.S Carbon tax: A lifetime and regional analysis.”Working Paper 13554 prepared for the United States National Bureau of Economic Research. 42p.

7. He, Y., Lizhi, W. \& Jianhui, W. (2012). “Cap-and-trade vs. carbon taxes: A quantitative comparison from a generation expansion planning perspective.” Computers and Industrial Engineering, 63(3): 708-716, November.

8. $\quad$ IPCC. (2012). "Climate Change 2007: Working Group II: Impacts, Adaptation and Vulnerability."Available: http://www.ipcc.ch/publications_and_data/ar4/wg2/en/ch20s20-6-1.html. Date of Access: 21 October 2012.

9. KYOTO. (2010). "Kyoto Protocol.” Available: http://www.kyotoprotocol.com. Date of Access: 28 August 2010.

10. Li, B., Fu, F.F., Zhong, H. \& Luo, H.B. (2012). "Research on the computational model for carbon emissions in building construction stage based on BIM." Structural Survey, 30(5): 411-425.

11. Liang, Q. \& Wei, Y. (2012). "Distributional impacts of taxing carbon in China: Results from the CEEPA model." Applied Energy, 92(4): 545-551. April.

12. Metcalf, G.E. (2009). "Market based policy options to control US greenhouse gas emissions." Journal of Economic Perspectives, 23(2): 5-27.

13. Midgely, G., Chapman, R., Mukheibir, P., Tadross, M., Hewitson, B., Wand, S., Shulze, R., Lumsden, T., Horan, M., Kgope, B.W., Mantiana, B., Knowles, A., Abayomi, A., Ziervogel, G., Cullis, R. \& Theron, A. (2007). "An input into the long term mitigation scenario process: LTMS Input Report 5.” Report prepared for the Department of Environmental Affairs South Africa and Tourism. 24p. (unpublished).

14. NAAMSA see National Association of Automobile Manufacturers of South Africa.

15. National Association of Automobile Manufacturers of South Africa. (2011). Quarterly Review of Business Conditions: New Vehicle Manufacturing Industry. Pretoria. 6p.

16. National Association of Automobile Manufacturers of South Africa. (2012). Quarterly Review of Business Conditions: New Vehicle Manufacturing Industry. Pretoria. 6p.

17. National Treasury. (2010). Discussion Paper for Public Comment: Reducing Greenhouse Gas Emissions: The Carbon Tax Option. Pretoria: Government Printer. 75p.

18. National Treasury. (2012). Media Statement: Taxation Laws Amendment Bills, 2012: General Overview. Pretoria: Government Printer.5p.

19. National Treasury \& South African Revenue Service. (2012). 2012 Tax Statistics. Pretoria: Government Printer. $185 \mathrm{p}$.

20. Nel, R. \& Nienaber, G. (2012). “Tax design to reduce passenger vehicle CO2 emissions.” Meditari Accountancy Research, 20(1): 39-51.

21. OANDA. (2012). “Average exchange rates.” Available: http://www.oanda.com/currency/average. Date of Access: 13 November 2012.

22. Pearce, D. (2003). "The social cost of carbon and its policy implications." Oxford Review of Economic Policy, 19(3): 362-384, November.

23. Shirley, B. (2010). "South Africa: Carbon Tax to Add Thousands to Cars."Available: http://www.businessday.co.za/Articles/Content.aspx?id=119959. Date of access: 28 December 2011.

24. Statistics South Africa. (2005 - 2011). Statistical releases P0302. Pretoria: Government Printer. July 2005 (RP 29/2005); July 2006 (RP 13/2006); July 2007 (RP 11/2007); July 2008 (RP 22/2008); July 2009 (RP 17/2009); July 2010 (RP 16/2010); July 2011 (RP 18/2011).

25. Tiezzi, S. (2005). "The welfare effects and the distributive impact of carbon taxation on Italian households.” Energy Policy, 33(1): 1597-1612. 
26. UN. (2012). "Carbon dioxide emissions (CO2), thousand metric tons of CO2 (CDIAC)." Available: http://mdgs.un.org/unsd/mdg/SeriesDetail.aspx?srid=749\&crid. Date of Access: 24 November 2012.

27. UNFCCC. (2010). "Kyoto Protocol”. Available: http://unfccc.int/kyoto_protocol/items/2830.php. Date of Access: 29 July 2010.

28. USG. (2012). "Social Cost of Carbon for Regulatory Impact Analysis under Executive Order 12866." Available: http://www1.eere.energy.gov/buildings/appliance_standards/ commercial/pdfs/sem_finalrule_appendix15a.pdf. Date of Access: 3 November 2012.

29. Wittneben, B.B.F. \& Kiyar, D. (2009). "Climate change basics for managers."Management Decision, 47(7):1122-1132.

30. WORLD BANK. (2012). "Passenger cars (per 1000 people)." Available: http://data.worldbank.org/indicator/IS.VEH.PCAR.P3. Date of Access: 1 December 2012.

31. WRI. (2012). "The Social Cost of Carbon and Climate Change Policy." Available: http://www.wri.org/stories/2011/07/social-cost-carbon-and-climate-change-policy. Date of Access: 13 November 2012.

32. WWF. (2012). "Carbon tax design options - A discussion document." Available: http://awsassets.wwf.org.za/downloads/carbon_tax_design_options_a_discussion_document_final_launch product 1.pdf. Date of access: 19 August 2012. 


\section{ANNEXURE A}

Company name:

Interviewee:

Date of interview:

Please allocate marks to each question as follows:

1. Do not agree

2. Do not agree subject to exceptions

3. Agree subject to exceptions

4. Strongly agree

\begin{tabular}{|c|c|c|c|c|}
\hline \multicolumn{5}{|l|}{ SECTION I: General } \\
\hline There is a definite need for a carbon excise tax on motor vehicles in South Africa. & 1 & 2 & 3 & 4 \\
\hline $\begin{array}{l}\text { I am aware of all carbon excise tax legislation and regulations applicable to the motor vehicle industry in } \\
\text { South Africa. }\end{array}$ & 1 & 2 & 3 & 4 \\
\hline $\begin{array}{l}\text { There are adequate internal controls over the recognition, measurement, recording and payment of carbon } \\
\text { excise tax applicable to motor vehicles. }\end{array}$ & 1 & 2 & 3 & 4 \\
\hline My company complies with all carbon excise tax legislation and regulations applicable to motor vehicles. & 1 & 2 & 3 & 4 \\
\hline \multicolumn{5}{|l|}{ SECTION II: Carbon tax impact and the social cost of carbon } \\
\hline $\begin{array}{l}\text { The implementation of carbon excise tax changed the production techniques and technologies toward } \\
\text { producing more fuel efficient vehicles. }\end{array}$ & 1 & 2 & 3 & 4 \\
\hline $\begin{array}{l}\text { The implementation of carbon excise tax has resulted in an improvement in the fuel efficiency of motor } \\
\text { vehicles manufactured. }\end{array}$ & 1 & 2 & 3 & 4 \\
\hline $\begin{array}{l}\text { The implementation of carbon tax has affected our company's corporate social investment policy and/or } \\
\text { behaviours. }\end{array}$ & 1 & 2 & 3 & 4 \\
\hline I am aware of the concept of the social cost of carbon. & 1 & 2 & 3 & 4 \\
\hline $\begin{array}{l}\text { The carbon tax price and revenue generated from its implementation adequately compensates for the } \\
\text { damage caused by carbon emissions from motor vehicles. }\end{array}$ & 1 & 2 & 3 & 4 \\
\hline Carbon tax is the best policy measure in addressing South Africa's climate change concerns. & 1 & 2 & 3 & 4 \\
\hline
\end{tabular}




\section{NOTES}

